\title{
Sülüs-Nesih Yazılarda Tavır Farkı: Hattat İsmâil Zühdî Efendi ve Hattat Ömer Vasfí Efendi'nin Sülüs-Nesih Meşk Murakkaalarının Karşılaştırılması
}

\author{
Dr. Öğr. Üyesi Özgür ÇETiNTAŞ \\ Bitlis Eren Üniversitesi \\ GSF, Geleneksel Türk Sanatları Bölümü \\ ozgurcetintas@gmail.com \\ ORCID: 0000-0001-6055-2892
}

\begin{abstract}
Öz
Sanat yaşayan bir fenomendir. Dolayısıyla sanatın evrildiğini, yani iyiye veya kötüye doğru değiştiğini gözlemlenmektedir. Bu anlamda Doğu'da i̇slâmiyet ve tasavvuf anlayışı, Avrupa'da Rönesans hareketleri sanat tarihi içerisindeki en büyük kırılma noktaları olarak düşünülebilir. Ancak tüm bu büyük hareketler içerisinde sanatın kendisi sürekli bir değişim halinde olmuştur. Bu değişme sanat dalları içerisinde ekollerle (usul) olduğu gibi, ekollerin ilerlemesi ise sanatçılar arasındaki tavır (üslûp) farklarıyla olmaktadır. Türk hat sanatı ekolünün ortaya çıkması 14. yüzyılda Amasyalı Hattat Şeyh Hamdullah sayesinde olmuştur. Hafız Osman ekolüne bağlı olmakla birlikte tavır (üslup) yönünden kendisini bir adım daha öteye taşıyan hattat, Türk hat sanatı ekolünde celi (iri) yazıların mihenk taşı olarak kabul edilen Mustafa Râkım Efendi'dir. Bu araş̧ırmada eserlerinden faydalanılan Hattat İsmâil Zühdî Efendi, Hattat Mustafa Râkım'ın hem ağabeyi, hem de ilk hocası olarak sanat tarihimizde yer almaktadır. Bu araştırma, Türk Hat Sanatı tarihinde önemli yere sahip olan Hattat İsmâil Zühdî Efendi ile Laz Hattat Ömer Vasfî Efendi arasındaki tavır farkını ve bu farkın hat sanatına olan katkılarını ortaya koymak amacıyla hazıllanmışıı. Bu sayede Türk hat sanatının gelişim sürecinde nelerin etkili olduğunu, yazı sanatında yapılan küçük değişikliklerin neleri etkileyebileceğini tartışmak da bu araştırmanın amaçları arasındadır. Zira bir hüsn-i hat eseri incelenirken nelere dikkat edilmesi gerektiği, bir eseri güzel veya çirkin olarak nitelerken hangi kriterlerin göz önüne alınması gerektiği bilgisi de çok önemlidir. Bu araştırmada aynı dönemde eserler vermiş olan iki hattatın, yine aynı tarzda olan eserinin mukayesesi yapılmıştır. Örnek olarak kullanılan yazılar hat sanatının öğretiminde "müfredat" olarak tercih edilen SülüsNesih meşk murakkaalarıdır.
\end{abstract}

Anahtar Kelimeler: Türk hat sanatı, ekol, tavır, sülüs, nesih, murakkaa, tezhip 


\title{
arts
}

Research Article

\section{A Comparison of Calligrapher İsmâil Zühdî Efendi and Calligrapher Ömer Vasfí Efendi's Thuluth-Naskh Mashqs Murakkaas}

\begin{abstract}
Art is a living phenomenon. So we observe that art evolves, that is, it changes towards good or evil. In this sense, the concept of Islam and Sufism in the East and Renaissance movements in Europe can be considered as the biggest breaking points in the history of art. However, among all these great movements, art itself has been in a state of constant change. This change, as with the schools (method) within the art branches, is the progress of the schools with the differences (style) of artists. The emergence of the Turkish calligraphy school was in the 14th century thanks to calligrapher Sheikh Hamdullah from Amasya. Although he is affiliated with Hafiz Osman school, the calligrapher who takes him one step further in terms of his style is Mustafa Râkım Efendi, who is accepted as the cornerstone of celi (large) writings in Turkish calligraphy. Calligrapher Hattat İsmâil Zühdî Efendi, whose works we will use in this research, is the brother and first teacher of Calligrapher Mustafa Râkım. This research has been prepared to reveal the style difference between Hattat ismâil Zühdî Efendi and Laz Hattat Ömer Vasfi Efendi, who have an important place in the history of Turkish Calligraphy, and their contribution to calligraphy. In this way, it is among the aims of this research to discuss what is effective in the development process of Turkish calligraphy, and what small changes in writing can affect. It is also very important to know what to consider when examining a work of calligraphy, and what criteria should be considered when describing a work as beautiful or ugly. In this research, comparisons of two calligraphers who produced works in the same period were compared. The texts used as examples are the sulusnaskh meshk murakkaa preferred as a "curriculum" in the teaching of calligraphy.
\end{abstract}

Keywords: Turkish art of calligraphy, school, style, thuluth, naskh, murakkaa, illumination 


\section{arts}

\section{GíRiş}

Her sanat dalında olduğu gibi Türk hat sanatında da ekoller görülmektedir. Bu ekoller Türk hat sanatına yön veren veya bu sanatın yönünü değiştiren bazı hattatlar tarafından yüzyıllar içinde oluşturulmuştur. Aslında hattatlar bu ekolleri oluşturmak için yola çıkmamışlardır. Kendilerinden önce gelen veya kendi dönemlerine mensup diğer hattatların yazılarında gördükleri hata, noksanlık veya geliştirilebilir hususları kendi estetik anlayışlarına göre değiştirdiklerinde ve bu anlayış daha öncekinin yerini aldığında ekoller ortaya çıkmış veya o hattatın tavrı belirginleşerek sanata yeni bir bakış açısı getirmiştir. Bu noktadan ele alındığında her hattat, kendinden önceki sanatçıların eksiklerini giderdiği gibi kendinden sonraki hattatlar için de yeni bir yol açmış olur. Açılan bu yeni yol bazen diğer hattatlar tarafından kabul görerek takip edilmiş bazen de terk edilerek zamanla yok olmuştur. Üçüncü bir seçenek olarak bu yollar terk edilmese de bu yolların izinde yeni ara yollar oluşmuştur. Ekoller, sanat dalları için, sanatı bütünüyle etkileyen ve yönlendiren köklü bir farklılık iken tavır, sanatçıyla alâkalı bir durum olarak etki alanı daha sınırıdır. Ekoller, sanatın kendisini etkilediği gibi toplumun sanat anlayışını ve estetik algısını da belli bir dönem için veya kalıcı olarak değiştirebilir. Tavır farkı ise sanatçıları birbirinden ayıran detaylar olarak düşünülebilir. Dolayısıyla bir sanat dalı içerisinde ekol oluşturabilmek ender rastlanılacak bir birikimin eseridir.

\section{Türk Hat Sanatında Ekol Sahibi Hattatlar}

Türk hat sanatında ekol sahibi hattatların başında hat sanatını Arap etkisinden çıkarıp Türk ekolünü geliştiren XV. yüzyılda yaşamış olan Hattał Şeyh Hamdullah Efendi (1436/1520) gelmektedir. Hat sanatını, Yâkut el- Musta'sımî tesirinden çıkarıp Türk ekolünü geliştiren Hattat Şeyh Hamdullah' 'ır. Tahminen 1485 yılında Osmanlı- Türk yazı sanatında Yâkut-ı Mustasımî devri kapanmış, Şeyh Hamdullah üslûbu doğmuştur (Derman, 1976, s. 54). Türk hattatlarının en büyüklerinden sayılan ve diğer önemli hattatlar tarafından "Kutbül- küttab, Gülzar-ı Bustân-i âdâb vb" diye vasıflandırıan Hattat Şeyh Hamdullah Efendi Türk yazı sanatına yaptığı hizmetle tebcil edilmeye lâyık görülmüştür (Celal, 1948, s. 5). İslam sanatları alanı (tezhip, minyatür, ebru) içerisinde çok önemli bir sanatçı olan HattatŞeyh Hamdullah Efendi, Türk hat sanatının temel karakterini ortaya koymuş ve altı yüzyıl sonra dahî taklit edilmeye çalışılmıştır. Günümüzde kullanılan harf ölçüleri, satır nizamı, harfler ve diğer çizgiler arasındaki 
münâsebetler ve daha birçok temel kural Hattat Şeyh Hamdullah Efendi'nin estetik zekâsının ürünüdür ve tüm bu nitelikleriyle İslam yazı sanatı sahası içinde Türk hat sanatı ekolünü oluşturmaktadır. Hattat Şeyh Hamdullah'tan sonra Türk hat sanatı ekolünün ilerlemesinde rol oynayan birçok hattat olmuştur Bu hattatların başında Hattat Şeyh Hamdullah'tan sonra Sülüs ve Nesih yazıda ekol sahibi olarak Hatta† Hâfız Osman'ı (1642/1698) anmak gerekir. Hattat Hafız Osman Hattat Şeyh'in yazılarına daha doğrusu harflerine ayrı bir güzellik katarak Aklâm-ı sitte'yi güzelliğin zirvesine ulaştırmıştır (Alparslan, 2004, s. 64). Hattat Şeyh Hamdullah'a ait yazılar incelenirken kendisinden önceki dönemin hattatlarının harf yapıları, harf ölçüleri, yazı âhengi, satır nizamı gibi hat sanatı için temel kaideler ve bu kaidelerde yaptığı değişiklikler dikkate alındığında kendisinin dehası ve sanata katkıları anlaşılmaktadır. Zîra temelleri Hattat Şeyh Hamdullah tarafından atılan Türk ekolü, sonraki hattatlar tarafından da benimsenmiş ve sürekli bir gelişmeyle günümüze kadar gelmiştir. Hattat Şeyh Hamdullah yolunu takip ederek Türk hat sanatı tarihinde büyük öneme sahip bir başka hattat da Hafız Osman' dır. Hafız Osman tarafından ilk kez denenen ve günümüze kadar kabul gören, taklit edilip farklı formları çalışılan Hilye-i Şerîfe levhaları hat sanatının vazgeçilmez eserleri arasındadır. Ondan sonra muhtemelen en önemli değişikliğe imza atan Mustafa Râkım Efendi olmuştur.

\section{Mustafa Râkım Efendi ve Hattat Ömer Vasfí Efendi}

Türk hat sanatında celi (iri) yazıların en doğru ve en göz alıcı biçimde yazılması Hattat Mustafa Râkım Efendi'nin başarısıdır. Hattatlar arasında önemli bir yeri olan Mustafa Râkım, başarısını ağabeyi Hattat İsmâil Zühdî Efendi'ye mâl etmektedir. Zîra Hattat İsmâil Zühdî, Türk hat sanatının çok önemli bir ekolü olan Hattat Hafız Osman ekolünü kendi devrinde geliştirerek en güzel biçimde temsil etmiş harf ve kelimelere zarif bir görünüş kazandırmıştır (Berk, 2003, s. 33). Ünye'de doğan Hattat İsmâil Zühdî Efendi Saray-ı Hümâyûn hattatı olmuş, 40'dan fazla Mushaf-ı şerif ve başka pek çok murakkaalar, levhalar yazmış ve 1806 yılında vefat etmiştir (Serin 1999, s. 154). Bu çalışmada kendisinden istifade edeceğimiz diğer Hattat Ömer Vasfî Efendi için "Hat ve Hattatân" adlı eserin 165. sahifesinde bilgi verilmiştir. Bu bilgiler ışığında Trabzonlu olduğu, bu sebeple Laz Hattat Ömer Vasfî adıyla tanındığı ve Enderun-ı Hümâyûn' da hocalık yaptığı bilinmektedir. Hattat Ömer Vasfî Efendi 1824 yllında vefat etmiştir (Hat ve Hattatân, Mirza Habib Efendi, H. 1325 https://archive. 


\section{arts}

org/details/hattvehattatan00qnabuoft/page/268). Türk Hat Sanatı tarihi içerisinde bilinen iki Hattat Ömer Vasfî vardır. Diğeri Hatib Hattat Ömer Vasfî Efendi' dir ki kendisi yaşadığı tarih itibariyle Hattat İsmâil Zühdî Efendi'nin çağdaşı değildir. 1880 yılında İstanbul'da doğmuştur (Serin 2003, s. 204). Bu makalede birbirine yakın dönemde yaşamış ve eserler vermiş olan Hattat İsmâil Zühdî ve Hattat Ömer Vasfî Efendilere ait birer murakkaa incelenerek hat sanatı bakımından kritik yapılacak ve iki hattatın tavır farklııkları ortaya konmaya çalışılacaktır. Bu karşılaştırmanın amacı yukarıda bahsedilen "hat sanatında tavır farkı" konusunu örnekler üzerinden açıklayabilmektir. Hüsn-i hat'ta âşina olmayanlar tarafından yazı çeşitlerinin birbirine karıştırıması çok doğaldır. Ancak bu sanata kısmen vâkıf olanların bile hattatlar arasındaki tavır farkını zaman zaman fark edemeyip, yazılardaki detayların gözden kaçırdığı da bilinmektedir. Aynı ekole mensup iki hattatın elinden çıkan Sülüs- Nesih meşk murakkaaları üzerinden yapılacak olan kıyaslama ile bu konuya açıkık getirilmeye çalışılacaktır.

\section{Murakkaa, Sülüs ve Nesih Yazıların Tanımı}

Her iki hattatın da sülüs-nesih meşk murakkaaları üzerinden yapılacak incelemeye geçmeden önce murakkaa, sülüs ve nesih yazılar hakkında kısa bir bilgi verilecektir. "Murakkaa; hattatların, ayrı ayrı kâğıtlara yazarak körük gibi bir ciltte topladıkları yazı albümü. Murakkaa albümleri çeşitli yazı türlerini içine alır" (Berk, 2013, s. 257). "Hat sanatında bir yazı türü. Hat sanatı örneklerini bir araya getiren birkaç sayfalık kitapçık. Eski Türk ciltçiliğinde, cilt kapağının ana malzemesini oluşturan üst üste yapıştııımış birkaç kałı mukavva" (Sözen, vd. 2014, s. 216). Son olarak murakkaa; hattat meşknâmesi, özel hazırlanmış bir kâğı üzerine yazılan meşk, güzel yazı örneği (Parlatır, 2009, s. 1133) olarak tanımlanmaktadır. Ikinci tanımda yer verilen sanat terimleri sözlüğünde geçen "hat sanatında bir yazı türü" ifadesi doğru bir ifade değildir. Hat sanatında en çok kullanılan altı yazı türü (Aklâm-ı sitte) sülüs, nesih, muhakkak, reyhani, tevki ve rık'a' dır. Bunlar arasında murakkaa diye bir yazı çeşidi olmadığı gibi, bilinen diğer yazı türleri içinde de murakkaa ismi geçmez. Ancak diğer tanımlar tamamen doğrudur. Mahmud Bedreddin Yazır (öl. 1952), "Kalem Güzeli" olarak bilinen kıymetli eserinin 78. sayfasında Sülüs Kalemi ve nesih yazı ile ilgili başığında bu yazı türleri için şu bilgileri vermiştir;

"Dört behresi musattah, iki behresi müdevverdir diye tarif olunmuştur" (Yazır, 
1981, s. 78). Yani sülüs yazıda kullanılan çizgilerin dört parçası düz forma yakınken iki parçası ise kavisli formdadır. Bu açıklamanın devamında sülüs yazının yazılacağı kalemin kalınlığı (ağız genişliği) için Tuhfe-i Hattatîn (Müstakimzâde Süleyman Saadeddin Efendi'nin M. 1759-60 yıllarında yazdığı ve hat sanatı hakkında bilgiler içeren eseri)' den bilgiler vermektedir. Ancak bu eserdeki bilgiler, yazıldığı dönem itibariyle eski ölçü birimlerinden olan şa'r (kıl) hesabına dayanmaktadır. Dolayısıyla günümüz ölçü birimine çevrildiğinde 2,5-3 mm olarak ifade edilmektedir. Nesih yazı içinse aynı eserde, sülüs kalemine tabi olup kalınlığı onun üçte biri kadardır şeklinde tarif edilmektedir. Bu yazı, teknik bakımdan sülüsün üçte ikisini neshetmiş (ortadan kaldırmış, yok saymış) ve üçte biriyle de ona tabi olmuştur. Bu sebeple nesih yazıda sülüs harfleri üçte bir nisbetinde küçültülmüş, dolayısıyla tam sülüs değil, onu andıran bir yazı formudur (Yazır, 1981, s. 78). Günümüzde diğer yazı karakterleri gibi, sülüs ve nesih yazılar da estetik anlamda oldukça ileri seviyelerdedir. Buna örnek olarak aşağıda günümüz hattatlarından Fatih Özkafa'ya ait bir koltuklu kıt'a'da sülüs ve nesih yazıları bir arada görülmektedir (Resim 1).

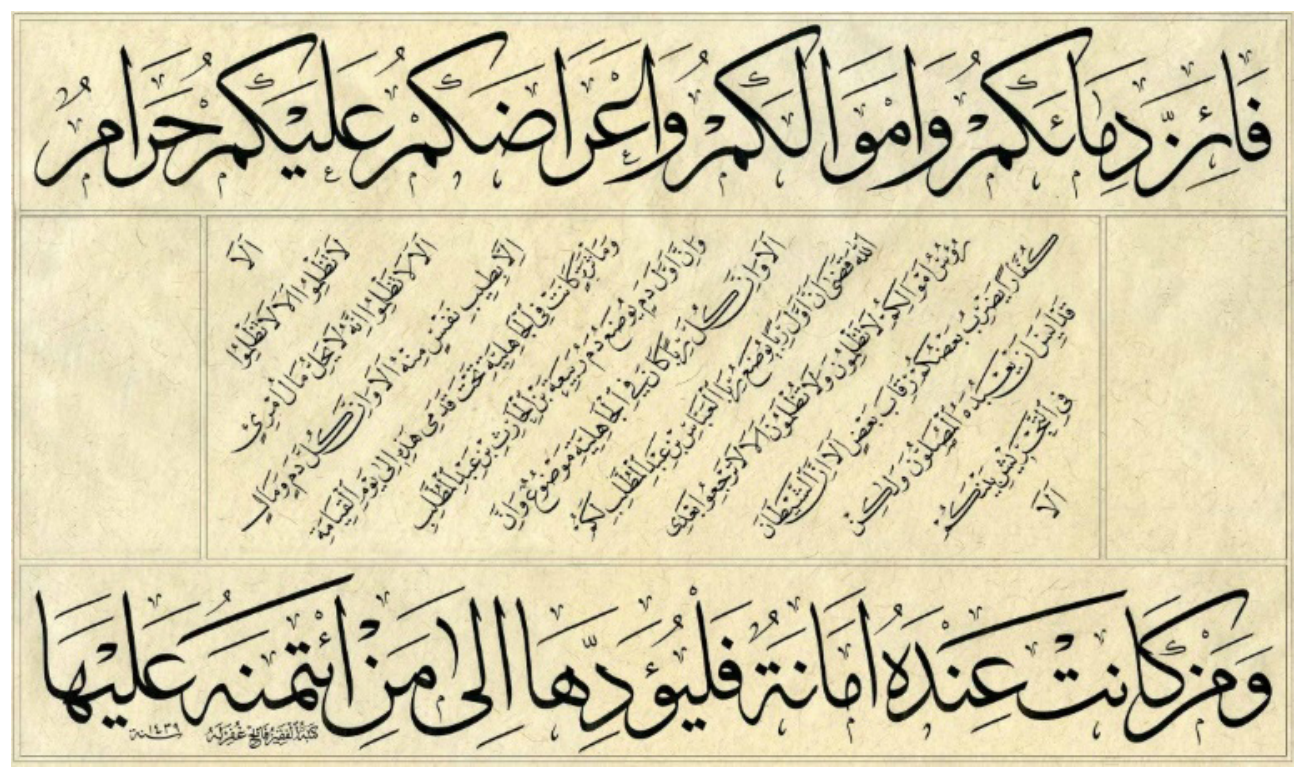

Görsel 1. Fatih Özkafa tarafından sülüs ve nesih yazı ile yazılmış bir kıt'a örneği. http://www.fatihozkafa.com/index.php?go=galeri (06.07.2019)

Günümüzhüsn-ihatsanatında harflerveyazı içerisindekitüm çizgilerkesinleşmiş ölçülerle yazılmaktadır. Bu sülüs-nesih kıtada dikkati çeken ilk özellik sanatta zıtlık ilkesidir. Bu ilkeye göre ilk satır ve son satırdaki sülüs yazıyı oluşturan harfler sola yatık bir görünüm arz ederken aradaki nesih yazı, satır nizamında yazılmadığı için aksi yönde bir harekete sahiptir. Nesih yazının sağında ve solunda kalan ve "koltuk" tabir edilen 
boşluklar ise dikey dikdörtgen biçimleriyle katı bir durağanlık hissi vermekte, yazıların birbirinden aksi yöndeki hareketleri ise zıtlık ilkesini pekiştirmektedir. Bu yazı hat sanatı kurallarına göre incelendiğinde harflerin ölçüleri, harfler arasındaki espas, satırların oluşturduğu düzgün hatlar, hareke ve tezyini işaretlerin leke değeri bakımından dengeli dağılımları geleneksel üslubu yansıtmakla beraber; günümüz estetik anlayışı içerisinde de kabul gören doğru ve güzel bir yazı olarak kendini beğendirmektedir. İzleyen kişide uyandırdığı sadelik, zıtlık ilkesiyle hissettirdiği hareket, mürekkep ve kâğı† rengi seçimiyle sahip olduğu ferahlık, hattatının başarısı olduğu kadar geleneksel sanatlarımızın günümüze kadar çok iyi şekilde korunarak geldiğini ve kendi kimliğini sanatçııına aktardığını da göstermektedir.

\section{Hattat İsmâil Zühdî ve Hattat Ömer Vasfî Efendi'nin Sülüs-Nesih Meşk Murakkaalarının Karşılaştırııması}

Geleneksel hat sanatımızın önemli sanatçılarından olan Hattat İsmâil Zühdî ve Hattat Ömer Vasfî Efendilere ait sülüs-nesih meşk murakkaalarının aynı sayfaları üzerinden yapacağımı değerlendirmeler, yazıları arasındaki tavır farkı kavramını açıklamamızda yardımcı olacaktır. Bahsi geçen eserler günümüzde Kanada-Toronto'daki Mc Gill University Library'de (https://archive.org/details/ mcgilluniversity) bulunmaktadır.

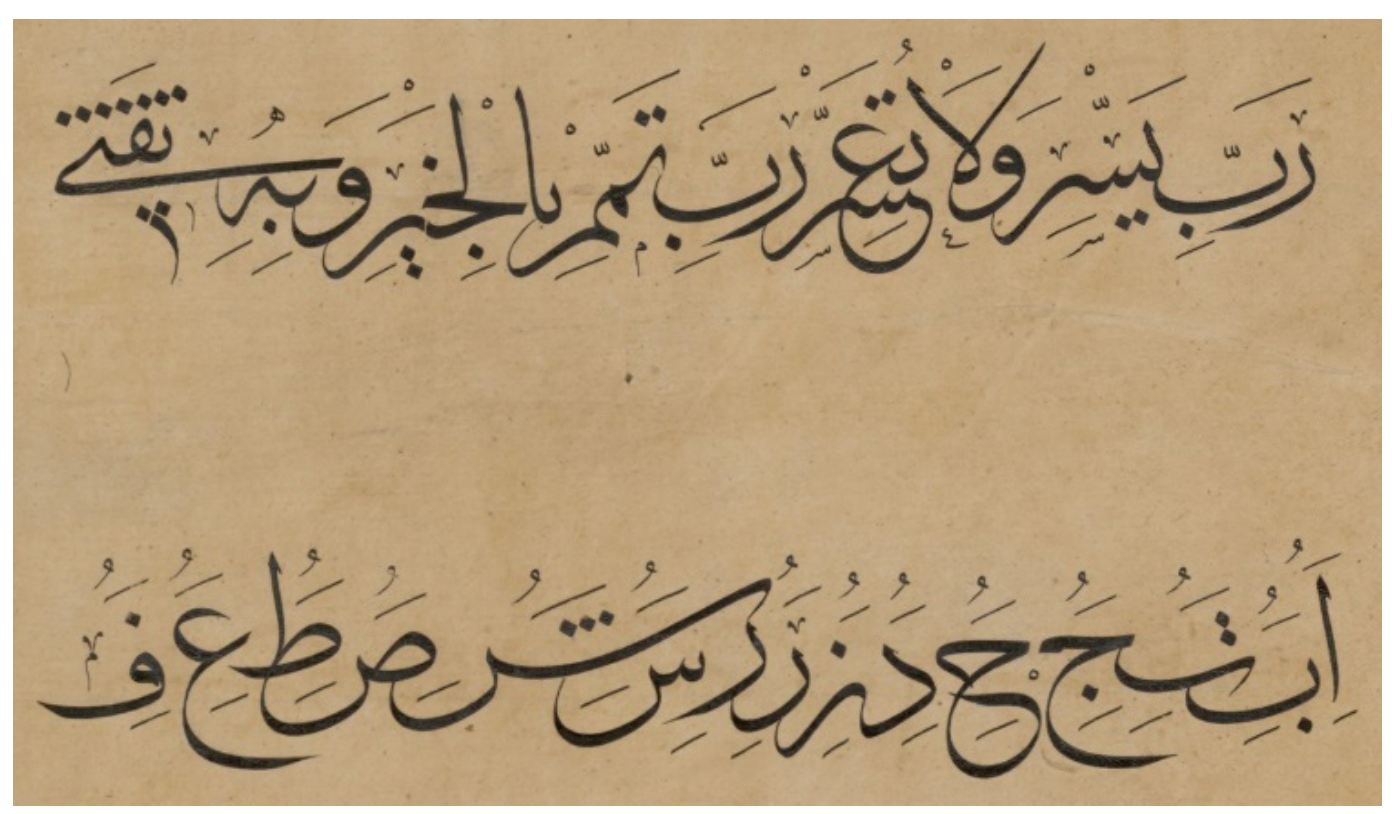

Görsel 2. Hattat İsmâil Zühdî Efendi'nin sülüs yazıyla yazdığı rabbiyessir ve harflerin ilk satırı 


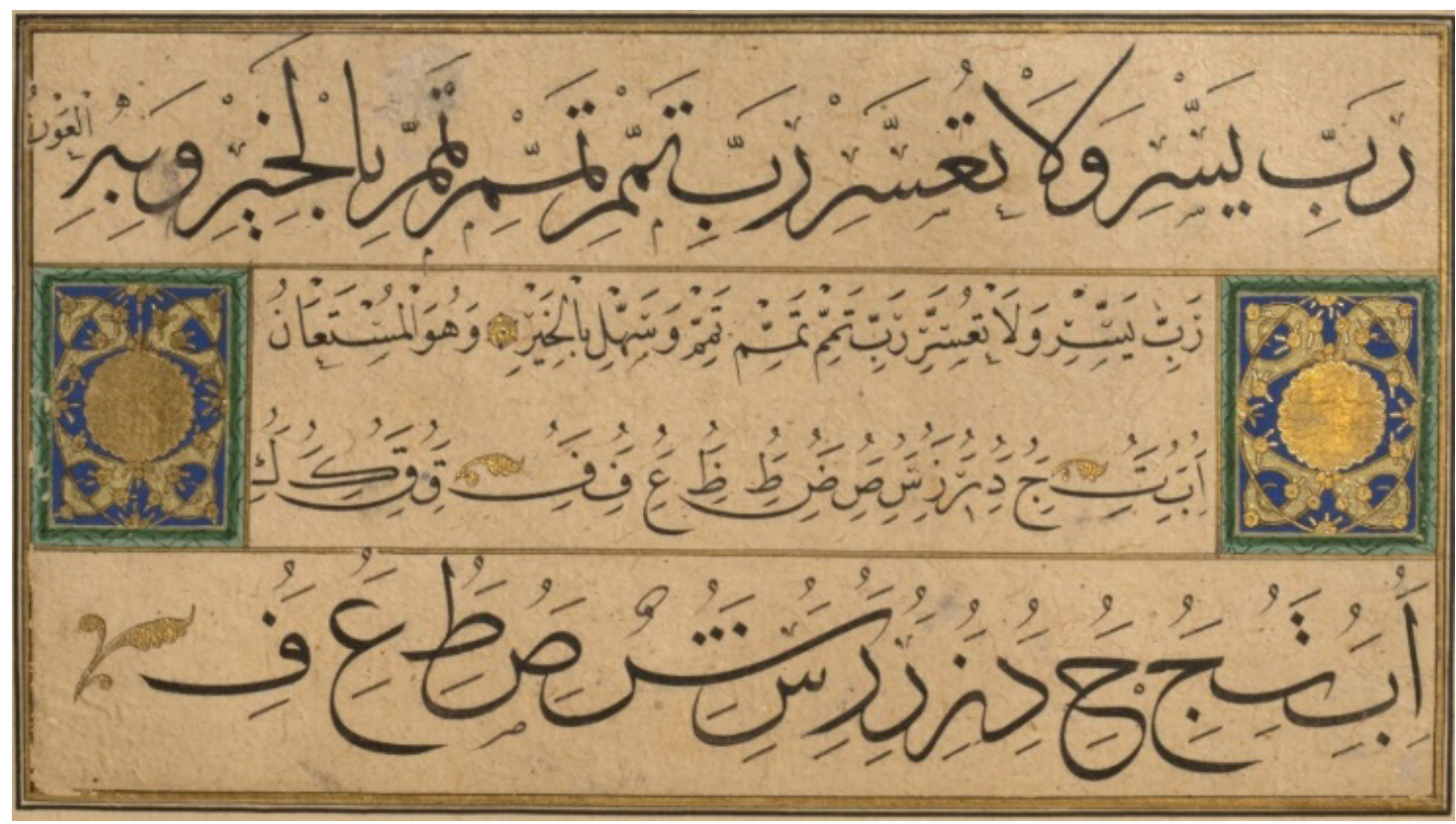

Görsel 3. Hattat Ömer Vasfî Efendi'nin sülüs yazıyla yazdığı rabbiyessir ve harflerin ilk satırı

Yazılara ilk bakışta Hattat İsmâil Zühdî Efendi meşkinde nesih yazının bulunmadığı dikkati çekmektedir. Bu durum bir tavır farkı değil, ancak tercih meselesidir. Dikkat çeken bir diğer önemli nokta ise Hattat Ömer Vasfî Efendi'ye ait yazıda tezhip, koltuk ve satır sonu süslemelerinin bulunmasıdır. Ancak bu da yazı kalitesini etkileyen bir durum değildir. Bu incelemede süsleme (tezhip) değil, yazılar dikkate alınacaktır. Her iki yazıda, hat sanatı bakımından ilk dikkat çeken nokta, satırların alt ve üst sınırlarıdır. Sülüs yazıda Hattat İsmâil Zühdî Efendi'nin satırları bir şerit gibi yaklaşık aynı hizaya sahip olmasına rağmen Hattat Ömer Vasfî Efendi'nin yazısına bakıldığında alt ve üstteki hareke ve tezyini işaretlerin belirli bir hizaya sahip olmadığı, inişli-çıkışlı bir çizgi izlediği görülmektedir. Ayrıca hareke dağııımında Hattat Ömer Vasfî Efendi'nin yazısı daha sıkışıkken Hattat İsmâil Zühdî Efendi harekeleri daha serbest ve ferah bir görünüm elde edecek şekilde yerleştirmiştir. Bu görünüm yazıda ferahlık, nefes alma duygusu yaratırken izleyen kişiyi de yormamaktadır. Harfler satırı incelendiğinde Hattat Ömer Vasfî Efendi' nin özellikle "Ha" ve "Cim (z)"-gibi küplü ve karınlı harflerinin eksenlerinin sağa meyilli olduğu, Hattat İsmâil Zühdî Efendi'de ise bunun tam tersine, bu harflerin hafifçe geriye doğru yaslanarak sola meyilli olduğu dikkati çekmektedir. Bu durum Arap yazısının ve kalem akışının tabiatına daha uygundur. Sağdan sola doğru yazılan Arap harfleri, tabii akışı içerisinde geriye doğru yatmaya meyillidir. Buradaki konu, harflerin satırdaki duruşları (kürsî), ağırlık merkezleri ve hacimleriyle ilgilidir. Hat sanatında harfler yalnızca bir çizgi olarak 
değil; ağırlığı, hacmi, denge noktaları olan üç boyutlu cisimler olarak düşünülür ki bu da hat sanatını sadece iki boyutlu veya çizgisel bir sanat olmaktan çıkarıp adeta yaşayan, elle tutulur bir varlık haline getirir. Böyle bir noktada harflerin ve onların etrafındaki diğer hareke ve tezyini işaretlerin, noktaların, kısacası her bir çizginin birbiriyle olan ilişkisi önem kazanır. Harfleri oluşturan her çizginin kendi içindeki uyumu, kalınlığı, derinliği, yuvarlaklığı, düzlüğü vs. bir araya gelerek bir bütün teşkil eder. Bu bütün içerisinde bir önceki veya bir sonraki elemanın uyumsuzluğu sadece kendi bünyesinde değil, yazının tamamında bir uyumsuzluk olarak görünecektir. Buradaki iki yazıyı incelediğimizde harf bünyelerindeki uyum, çizgilerin birbiriyle bağlandığı kısımlardaki zarafet, harflerin etraflarında bulunan diğer elemanlarla ilişkileri bir bütünlük arz etmektedir. Bu incelemede yer verilen iki hattatın da aynı ekole bağlı oldukları bilinmektedir. Ancak her iki yazıda yer alan "Tı (b)" harfleri başta olmak üzere harflerin kuyrukları, çanak dönüşleri ve "Sin", "Sad (ص,س)" gibi harflerin çanaklarının denge merkezlerinin farklı olduğu görülebilmektedir. Aynı ekole tabi olan iki hattał arasındaki bu fark ancak tavır farkı olarak değerlendirilebilir. Burada yapılan tarifler iki hattattan birinin diğerine üstünlüğünü göstermez. Doğru ölçülerde ve doğru istif kurallarıyla yazılan her yazı doğru kabul edilebilir. Anlatımak istenen, hüsn-i hat gibi kałı kuralları ve ölçüleri olan bir sanat içerisinde dahi farklılıkların oluşabileceği ve sanatçının kendi karakterinden, duygu dünyasından katkılarla bu geleneksel sanatı biçimlendirebileceğidir.

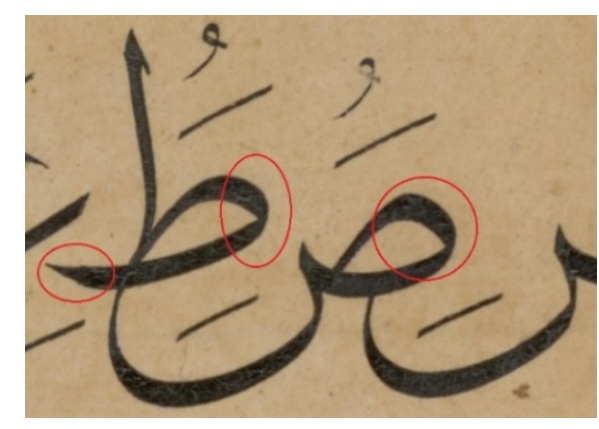

Görsel 4. Hattat İsmâil Zühdî Efendi

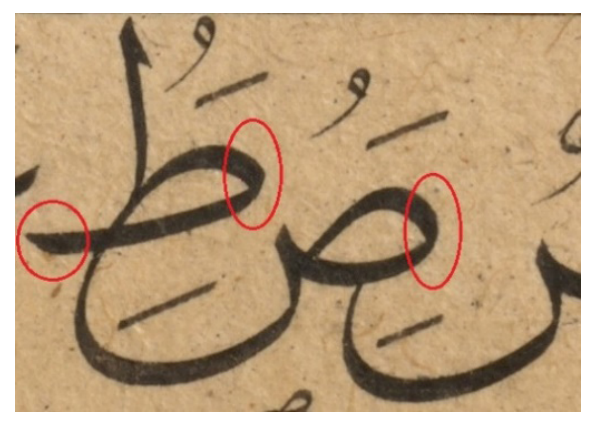

Görsel 5. Hattat Ömer Vasfi Efendi

Yine harf bağlantılarına dikkatle bakıldığında Hattat İsmâil Zühdî Efendi'nin "sad" ve "†ı (ط, (ط)" bağlantılarında daha yuvarlak ve yumuşak bir geçiş yaptığı; Hattat Ömer Vasfî Efendi'ninse özellikle "tı (b)" bağlantısındaki gibi görece daha keskin ve daha sert bir bağlantıyı tercih ettiği görülmektedir. Bu bağlantı noktaları harfin ölçüsünde bir değişiklik yaratmamakta ancak genel itibarla yazıya sert bir 
mizaç katmaktadır. Zira "†ı (b)" harfinin gözünü oluşturan boşluklar her iki yazıda dikkatle incelendiğinde Hattat İsmâil Zühdî Efendi'de daha dairesel, Hattat Ömer Vasfî Efendi'de daha düzümsü ve basık olduğu görülmektedir.

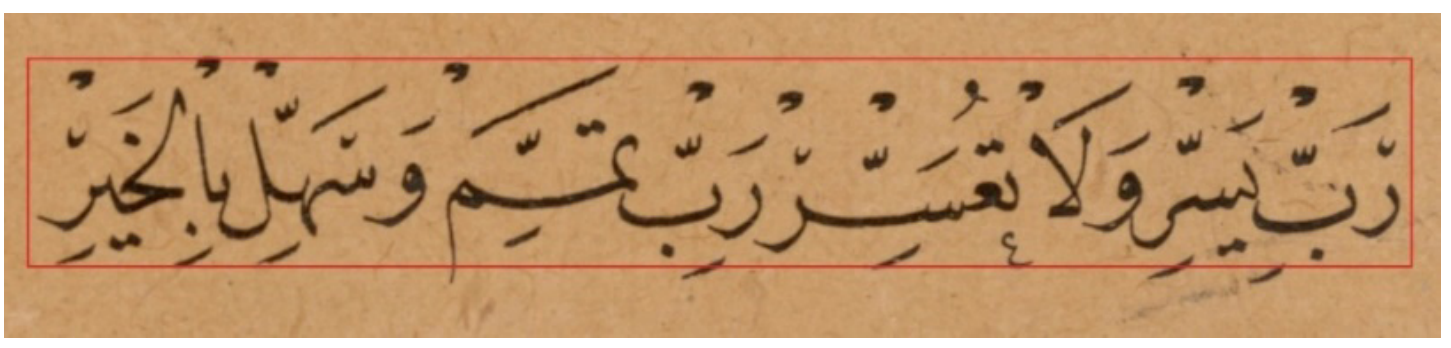

Görsel 6. Hattat İsmâil Zühdî Efendi'ye ait Nesih rabbiyessir

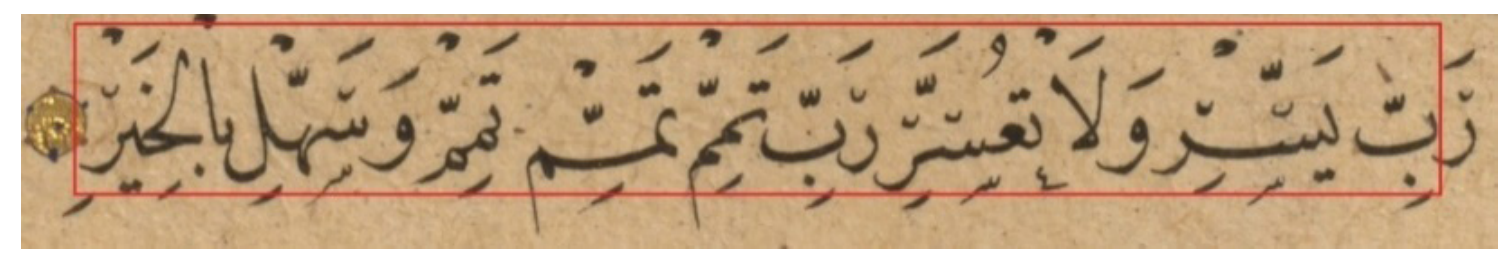

Görsel 7. Hattat Ömer Vasfî Efendi'ye ait Nesih rabbiyessir

Bu bölümde nesih yazıları incelediğimizde, sülüs yazıda yer alan farkllıklar yine karşımıza çıkmaktadır. Hattat Ömer Vasfî Efendi' nin yazısındaki sıkışıklığa karşılık Hattat İsmâil Zühdî Efendi'nin yazısı daha ferah bir görünüm sunmaktadır. Hem harekelerin dağılımında hem de harfler arasında bu farklılık görülmektedir. Hattat Ömer Vasfî Efendi'nin nesih satırı, sülüs satırına göre daha belirgin bir çerçeve içine oturmaktadır. Hattat İsmâil Zühdî Efendi ise bu durumu her iki yazı karakterinde de göstermektedir.

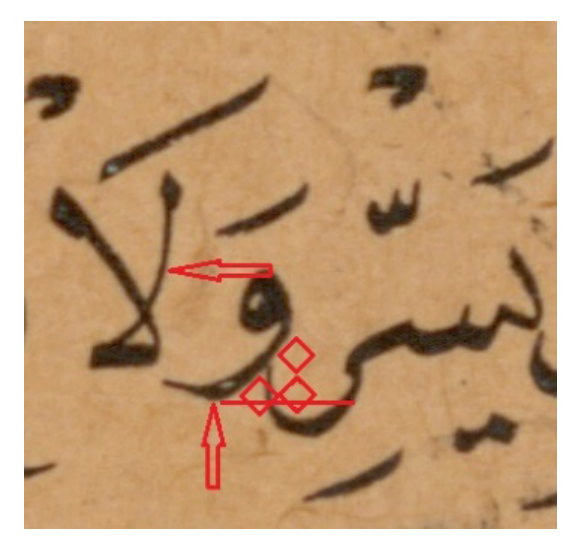

Görsel 8. Hattat İsmâil Zühdî Efendi

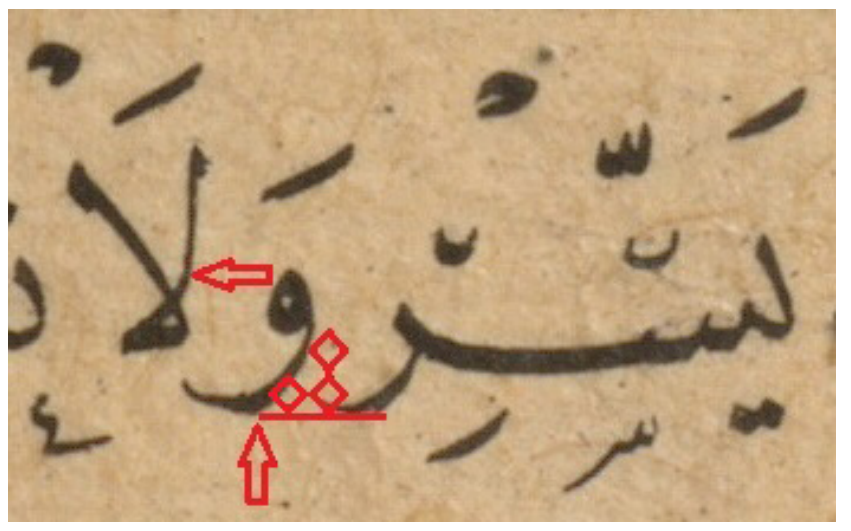

Görsel 9. Hattat Ömer Vasfî Efendi 


\section{$\operatorname{arts}=$}

Bu aşamada nesih yazıda her iki hattatın harflerini tavır bakımından incelediğimizde sert ve yumuşak karakterler yine ön plana çıkmaktadır. Hattat İsmâil Zühdî Efendi' nin "Vav (و)" harfini oluşturan parçalardan ilki olan "vav (و) başı" hafif aşağı dönük duruşu ve yuvarlak dönüşleriyle yumuşak bir tavır gösterirken Hatta† Ömer Vasfí Efendi'nin "Vav (و) başı" daha düz bir duruşla sola bakmakta; çene ve tepe dönüşlerindeki daha sivri hatlarıyla sert bir görünüm sunmaktadır. Aynı harfin çanak kısımlarını incelediğimizde Hattat İsmâil Zühdî Efendi daha sola giderek derinliği ve devamında gelen dönüşün sivriliğini azaltmış, Hattat Ömer Vasfî Efendi ise daha dik inmiş ve buna bağlı olarak daha keskin dönmüştür. Bu hareketleri takiben Hattał Ömer Vasfî Efendi'nin "Vav (و)" harfinin büyük kısmı satııın (kürsînin) altına sarkmıştır. Hattat İsmâil Zühoî Efendi'nin "vav (و)" harfinde daha dengeli bir duruş görülmesinin sebebi harfin, satııın altında ve üstünde eşit hacminin bulunmasıdır. Yine "Lâmelif (ل)" harflerine baktığımızda harfin sağ tarafındaki çizginin (lam / ل) kııılma noktasının Hattat Ömer Vasfî Efendi' de daha sert; Hattat İsmâil Zühdî Efendi' de daha yumuşak bir geçişe sahip olduğunu görmekteyiz. Hem "Vav (و)" hem de "Lâmelif (ل)" harflerinin ortak özellikleri olarak iki harfin de gözlerinin Hattat İsmâil Zühdî Efendi' de daha açık, Hattat Ömer Vasfî Efendi'de daha kapalı olmasının sebeplerinden biri dönüşlerdeki keskinlik ile iniş ve çıkışlardaki sivriliktir. Birbirine çok yakın veya aynı ölçülerde yazılan iki yazının bu kadar farklı detaylara sahip olması iki hattatın tavır farklı̈ı̆ından kaynaklanmaktadır. Daha önce belirttiğimiz gibi bu farklııklar bir hattatın diğerine üstünlüğünü değil, yalnızca sanat ve estetik anlayışlarının birbirinden farklı olabileceğini gösterir.

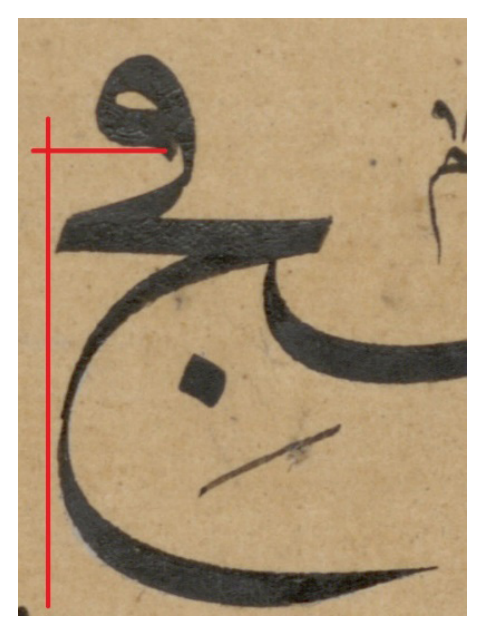

Görsel 10. Hattat İsmâil Zühdî Efendi

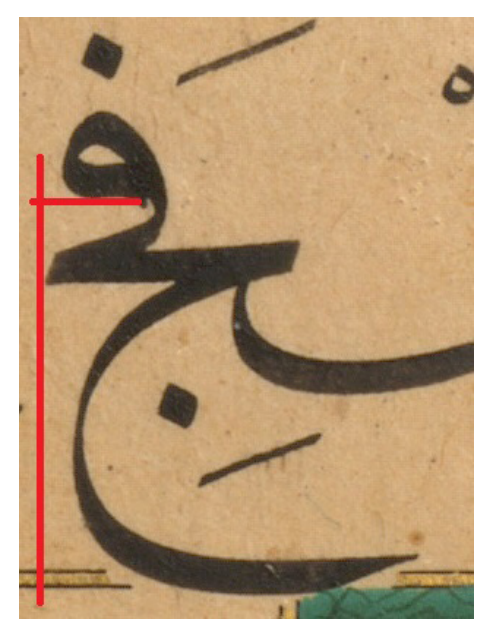

Görsel 11. Hattat Ömer Vasfî Efendi 
Yukarıdaki fotoğraftaki sülüs harf bağlantılarına baktığımızda ilk göze çarpan, harf kütlelerinin duruşlarıdır. Bütün olarak incelendiğinde Hattat Ömer Vasfî Efendi'nin harf kütlesi sola doğru meylederek dengeli bir duruş göstermemektedir. Buna karşllık Hattat İsmâil Zühdî Efendi'nin harfleri daha dengeli bir duruşa sahiptir. Bu görüntünün başlıca sebebi birbirine bağlanan harflerin, birbirinden farklı istikamette çizgilere sahip olmasıdır. Bağlantının ilk elemanı olan "fe (ف)" harfi, başlangıç ve bağlantı çizgisi itibariyle sola doğru seyretmektedir. Devamında gelen "cim (ج)" harfi ise başlangıç ve bitiş çizgileri itibariyle sağa doğru seyretmektedir. Bu harflerin bağlantısındaki denge unsurunun bir diğer önemli noktası da çizgilerin satırın altında ve üstünde kalan kısımları ile cim harfinin karın çizgisinin ağırlık merkezidir. Hattat İsmâil Zühdî Efendi'nin "cim (ج)" harfinde ağırlık merkezi dış hatta yakın ve zeminden yukarıdadır. Hattat Ömer Vasfî Efendi'de ise karın dönüşü dış hattın içinde ve zemine daha yakındır. Bir başka dikkat edilmesi gereken nokta da "fe (ف)" harfinin alt çizgisinin istikametidir. Hattat İsmâil Zühdî Efendi'nin "fe (ف)" harfi hafif yukarı doğru çıkan bir çizgiyle başladığı için hemen altındaki bağlantı çizgisinin inişini dengelemektedir. Hattat Ömer Vasfî Efendi'nin "fe (ف)" harfi daha düz bir çizgiyle başladığı için alıındaki bağlantı parçasının inişini karşılayamamaktadır. Bu sebeple harf bünyesi geriye doğru yıkılan bir görünüm sunmaktadır.

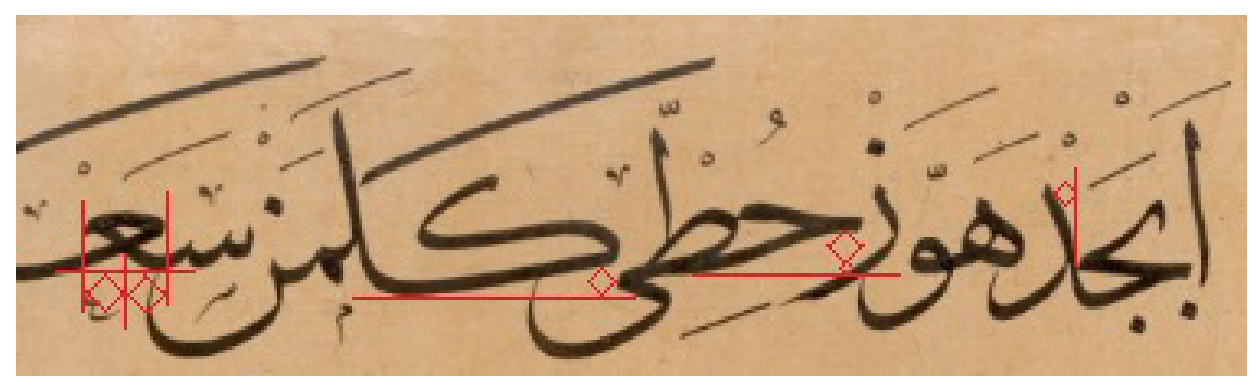

Görsel 12. Hattat Ismâil Zühdî Efendi'nin ebced satırı

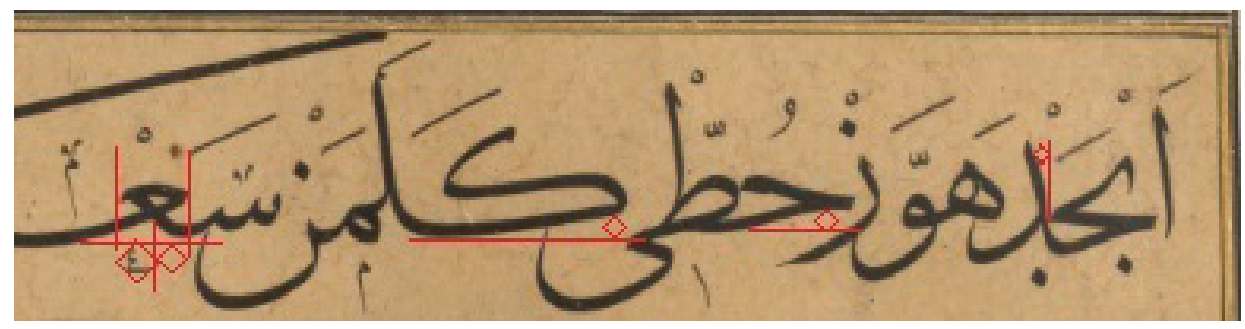

Görsel 13. Hattat Ömer Vasfî Efendi'nin ebced satırı 


\section{$\operatorname{arts}=$}

Son olarak her iki hattatın murakaasındaki ebced satırlarını incelediğimizde istiflerinin ve hatta hareke dağılımlarının neredeyse aynı olduğunu görmekteyiz. Buna karşılık harflerin duruşlarındaki detaylar yazıları birbirinden ayırt etmemize imkân vermektedir. İlk başta bahsettiğimiz yazının bir çerçeve içinde yer almasına dâir farklılık yine göze çarpmaktadır. Hattat İsmâil Zühdî Efendi'nin yazısı harflerin alt hizaları ve üstteki harekelerin dağlımıyla bir çerçeve içine yerleştirilmişken, Hattat Ömer Vasfî Efendi'nin satııında bu görüntü yoktur. Yine Hattat İsmâil Zühdî Efendi'nin harekeleri yerleştirirken yazıyı sıkıştırmadan, serbest şekilde yerleştirmesine karşılık Hattat Ömer Vasfi Efendi'nin harekeleri harflere daha yakın durmakta, bu sebeple yazının dolu alanlarının sıkışık, boş alanlarının ise çok seyrek kaldığı gözlemlenmektedir. Harf bünyelerindeki duruş farklılıkları işaretlenmiş olup, tavır farkının bir yansıması olarak belli edilmeye çalışılmıştır. Son bir husus olarak Hattat İsmâil Zühdî Efendi ve Hattat Ömer Vasfî Efendi'nin yazılarını hareke dağılımı bakımından incelediğimizde, Hattat İsmâil Zühdî Efendi'nin yazısında ince ve kalın çizgilerin birbiri arasında dengeli dağıldığını; Hattat Ömer Vasfî Efendi' de ise bir gruplaşma veya katmanlar olduğunu söyleyebiliriz. Arap yazısında harekeler, harfleri okutucu veya seslendirici tesire sahiptir. Dolayısıyla bağlı oldukları harfin alanında yer almaları gerekir. Bu sebeple yerleri değiştirilemez. Ancak aşırıya kaçılmamak koşuluyla bir miktar uzatılıp kısaltılabilirler. Hattat İsmâil Zühdî Efendi' nin yazısındaki ince ve kalın çizgilerin bu yolla birbiri arasına karışması genel bir denge ve hareket unsuruna dönüşmüştür. Hatta† Ömer Vasfî Efendi' de ise hem harekelerin yani ince çizgilerin harflere-kalın çizgilereyakın durması yazıya bir ağırlık katmış, hem de neredeyse aynı boyda harekeler kullanılması nedeniyle de yazıda bir durağanlık oluşturmuştur.

\section{SONUÇ}

Aynı devirlerde yaşamış ve birbirine yakın tarihlerde eserler veren, aynı ekole mensup bu iki hattatın sülüs-nesih meşk murakkaaları üzerinden yapılan karşılaşııma, hüsn-i hat sanatı gibi kesin kurallarla bağlı bir sanatta dahi sanatçının kimliğini, sanat anlayışını, estetik zevkini gösterebilecek nitelikte değişiklikler yapılabileceğini göstermiştir. Bu değişiklikler sanatın geleneğini ve yapısını olumsuz yönde etkilememiş, aksine Türk Hat Sanatı tarihi içerisinde farklı ekoller oluşmasına vesile olarak sanatı, yerinde saymaktan kurtarmış ve günümüze kadar zenginleşerek gelmesini sağlamıştır. Bu durum şunu göstermektedir ki bir sanat dalının gelişiminde 


\section{$\operatorname{arts}=$}

kısa zamanda yapılan büyük değişiklikler kadar yüzyıllara yayılan küçük ayrımlar da etkili olmaktadır. Bu araştırmanın sonucunda ortaya çıkan fikir odur ki Hafız Osman ekolüne mensup iki hattat, aynı yazı karakterlerini birbirlerinden ayırt edilecek şekilde yazabilmiştir. Yazıların ölçüleri aynı olsa da harflerin duruşu, harekelerin ve tezyini işaretlerin kalınlıkları, kapladıkları alan, satırların oluşturduğu hatlar ve çizgilerin ağırlık merkezleri hattatlara göre değişebilmektedir. Bu durum yani hattatların eserlerindeki tavır farklııkları sanatın zenginleşmesine katkı sunmaktadır.

\section{KAYNAKÇA}

Alparslan, A. (2004). Osmanlı Hat Sanatı Tarihi. İstanbul: Yapı Kredi Yayınları.

Berk, S. (2003). Hattat Mustafa Rakım Efendi hayatı, san' atı ve eserleri. İstanbul: Kaynak Yayınları.

Berk, S. (2013). Devlet-i Aliyye'den Günümüze Hat Sanatı. İstanbul: İnkılab Yayınevi.

Celal, M. (1948). Hattat Şeyh Hamdullah. İstanbul: Kenan Matbaası.

Derman, M. U. (1976) İslâm sanatında Türkler içinde hat sanatında Türklerin yeri. İstanbul: Yapı ve Kredi Bankası Yayınları.

Hillenbrand, R. (2005). İslam sanatı ve mimarlığı. İstanbul: Homer Kitabevi.

Parlatır, İ. (2009). Osmanlı Türkçesi sözlüğü, Ankara: Yargı Yayınevi.

Serin, M. (2003). Hat Sanatı ve Meşhur Hattatlar. İstanbul: Kubbealtı Neşriyatı.

Sözen, M. - Tanyeli, U. (2014). Sanat Kavram ve Terimleri Sözlüğü. İstanbul: Remzi Kitabevi.

Yazır, M. B. (1981). Medeniyet Aleminde Yazı ve İslam Medeniyetinde Kalem Güzeli. Ankara: Diyanet İşleri Başkanlığı Yayınları.

Hattat İsmâil Zühdî Efendi ve Hattat Ömer Vasfî Efendi. "Sülüs-nesih Meşk Murakkaası" (H. 1220) 22 Nisan 2019. <https://archive.org/details/mcgilluniversity>

Mirza Habib Efendi. "Hat ve Hattatan" (H. 1305) 14 Mayıs 2019. <https:// archive.org/details/hattvehattatan00qnabuoft/page/268>

Özkafa, Fatih. "Sülüs-nesih Kıta" (H. 1439) 6 Temmuz 2019. <http://www. fatihozkafa.com/index.php?go=galeri> 